\title{
Molecular cloning and regulation of porcine SULT2A1: relationship between SULT2A1 expression and sulfoconjugation of androstenone
}

\author{
P A Sinclair, W J Gilmore, Z Lin, Y Lou and E J Squires \\ Department of Animal and Poultry Science, University of Guelph, Guelph, Ontario, Canada N1G 2W1 \\ (Requests for offprints should be addressed to E J Squires; Email: jsquires@uoguelph.ca)
}

\begin{abstract}
Hydroxysteroid sulfotransferase (SULT2A1) is a key enzyme in the testicular and hepatic metabolism of $5 \alpha$-androstenone, which is a major component of the off-odor and off-flavor in pork known as boar taint. The goals of this study were to determine the role of testicular and hepatic SULT2A1 activity on plasma $5 \alpha$-androstenone sulfate levels, the accumulation of $5 \alpha$-androstenone in adipose tissue, and to gain insight into the regulatory control of SULT2A1. Testicular SULT2A1 activity was negatively correlated $(r=-0.57 ; P<0.01)$ with $5 \alpha$-androstenone concentrations in fat. The differences observed in SULT2A1 activity warranted investigation into potential genetic variation within porcine SULT2A1. The cDNA sequence of porcine Sult2A1 was determined to be $>82 \%$ homologous to the human, mouse, and rat Sult2A1 genes. A single nucleotide polymorphism was detected within the coding region of the Sult2A1 from individual testes and liver samples; however, this did not affect the amino acid sequence of the enzyme. Western blot analysis determined that animals with high concentrations of $5 \alpha$-androstenone in fat and low SULT2A1 activity had corresponding low levels of SULT2A1 protein compared with animals with low levels of $5 \alpha$-androstenone in fat. Real-time PCR analysis indicated that Sult2A1 mRNA was increased 2.8-fold in animals with high levels of the protein relative to animals with low levels of the protein. Furthermore, we demonstrated the positive role of the nuclear receptors constitutive androstane receptor and pregnane $\mathrm{X}$ receptor, as well as the possible role of farnesoid $X$ receptor in the regulation of testicular SULT2A1 activity. Together, the results of this study suggest that differences in SULT2A1 expression can influence $5 \alpha$-androstenone accumulation in fat.
\end{abstract}

Journal of Molecular Endocrinology (2006) 36, 301-311

Sulfotransferase enzymes are cytosolic proteins involved in catalyzing the conjugation of many steroids, bile acids, and xenobiotics. Sulfotransferases utilize the donor molecule 3'-phosphoadenosine 5'-phosphosulfate (PAPS) for the transfer of a sulfate radical $\left(\mathrm{SO}_{3-}\right)$ to a hydroxyl acceptor site. In terms of steroids, hydroxyl groups at positions 3, 21, and 17 of the steroid nucleus are the most common locations for sulfoconjugation (Strott 1996). With the addition of the sulfate group, the polarity of the steroid conjugate is greatly enhanced, causing an increase in water solubility Jakoby et al. 1980). Therefore, sulfoconjugation of hydroxysteroids has been regarded as a major mechanism for their metabolism and excretion (Strott 2002).

Steroid sulfotransferase enzymes are located in many different organs such as the liver, adrenal gland, ovary, and testis (Gasparini et al. 1976, Hobkirk 1985). In the boar, the testis is the main organ responsible for steroid sulfate synthesis (Raeside \& Renaud 1983, Hobkirk et al. 1989). One of the major steroid sulfotransferases is hydroxysteroid sulfotransferase, which has very wide substrate specificity. Its primary substrate is dehydroepiandrosterone (DHEA), and thus it was originally named
DHEA-sulfotransferase (Comer et al. 1993). In recent years DHEA-sulfotransferase has been further classified to the 2A family of human sulfotransferases, and is designated as SULT2A1 by the HUGO Nomenclature Committee (www.gene.ucl.ac.uk/hugo/index.html).

Hydroxysteroid sulfotransferase is responsible for sulfoconjugating the 16-androstene steroids (Sinclair \& Squires 2005), which have pheromonal properties and are the most abundant steroids produced by the boar testes. The accumulation of high levels of the 16-androstene steroid, $5 \alpha$-androstenone, in adipose tissue produces an unpleasant odor when the meat from intact males is cooked (Patterson 1968). Our previous studies have indicated that increased levels of sulfoconjugated 16-androstene steroids present in the systemic circulation are associated with a reduction in the accumulation of $5 \alpha$-androstenone in adipose tissue (Sinclair \& Squires 2005). However, the relationship between SULT2A1 activity in the testis and liver, and the concentration of sulfoconjugated 16androstenes in the circulation has not been demonstrated.

In humans, SULT2A1 activity varies up to five-fold among individuals (Weinshilboum \& Aksoy 1994), suggesting that genetic polymorphisms may be involved 
in regulating SULT2A1 activity. A number of studies reported single nucleotide polymorphisms (SNPs) within the human Sult2A1 gene (Igaz et al. 2002), some of which have resulted in reduced levels of both enzyme activity and protein (Thomae et al. 2002). Furthermore, research in both human and rodent SULT2Al regulation has revealed that this gene may be controlled by various nuclear receptors including the constitutive androstane receptor (CAR) (Saini et al. 2004), the pregnane X receptor (PXR) (Kliewer et al. 1998, Duanmu et al. 2002, Echchgadda et al. 2004), and the farnesoid X receptor (FXR) (Makishima et al. 1999, Song et al. 2001). However, the involvement of nuclear receptors in the regulation of porcine SULT2A1 has not been determined.

The initial goal of this study was to determine whether differences in testicular and hepatic SULT2A1 activity are related to levels of sulfoconjugated 16-androstenes in blood, and thus, the capacity for $5 \alpha$-androstenone to accumulate in adipose tissue. Because of the significant role of sulfoconjugation of the 16-androstene steroids in the development of boar taint, it was important to understand the molecular basis for individual variation in the expression and function of the SULT2A1 gene in market weight boars. Therefore, the porcine Sult2A1 cDNA was cloned and sequenced, and genetic polymorphisms in the Sult2A1 gene that may cause alterations in enzyme function were examined. In addition, the regulatory control of SULT2A1 activity by various nuclear receptor ligands was investigated.

\section{Materials and methods}

\section{Reagents}

Sep-Pak $\mathrm{C}_{18}$ solid-phase chromatography cartridges were purchased from Waters Ltd (Mississauga, ON, Canada). HANKS balanced salt solution (HBSS) was obtained from Invitrogen Life Technologies (Burlington, ON, Canada). Radiolabeled $\left[{ }^{3} \mathrm{H}\right]$ DHEA and DHEA sulfate (DHEAS) (approximately $0.01-0.05 \mu \mathrm{Ci} / \mathrm{nmol}$ ) were obtained from ICN Diagnostics (Montreal, QC, Canada). $5 \alpha$-Androstenone was obtained from Steraloids Inc. (Newport, RI, USA) and 6-(4-chlorophenyl)imidazo [2,1-b] [1,3]thiazole-5-carbaldehyde O-(3,4-dichlorobenzyl) oxime (CITCO) was obtained from Biomol Research Laboratories Inc. (Plymouth Meeting, PA, USA). Pregnenolone 16 $\alpha$-carbonitrile (PGN), 1,4-bis-[2-(3,5dichloropyridyl-oxy)] benzene; 3, $3^{\prime} 5,5^{\prime}$-tetrachloro-1,4-bis (pyridyl-oxy)benzene (TCPOBOP) and all other reagents were obtained from Sigma-Aldrich Ltd (Mississauga, ON, Canada).

\section{Tissue samples}

A total of 28 Yorkshire boars (group A) of $175 \pm 6$ days of age were obtained from the Arkell Swine Research
Station at the University of Guelph, Guelph, ON. Procedures were approved by the Animal Care Committee at the University of Guelph and animals were cared for according to the Canadian Council on Animal Care requirements. Blood samples were taken from the orbital sinus, centrifuged at $4{ }^{\circ} \mathrm{C}$ to collect plasma and stored at $-20^{\circ} \mathrm{C}$ until extraction and analysis for $5 \alpha$-androstenone concentrations.

The animals were slaughtered at an average live weight of $125 \pm 13 \mathrm{~kg}$. A backfat (adipose tissue) sample was removed from the midline on the point of the 11th rib and frozen at $-20{ }^{\circ} \mathrm{C}$ until assayed for $5 \alpha$ androstenone. Samples of liver and testis tissue were taken immediately following exsanguination, frozen in liquid nitrogen and stored at $-70^{\circ} \mathrm{C}$ until needed.

An additional three mature Yorkshire boars (group B) of $175 \pm 6$ days of age were used for the isolation of Leydig cells. After slaughter, the testes were immediately removed and transported to the laboratory within $5 \mathrm{~min}$. Testicular tissue was sliced into pieces of $1 \mathrm{~cm}^{2} \times$ 2-3 mm thickness and $100 \mathrm{~g}$ tissue samples were incubated for $20 \mathrm{~min}$ in a shaking water bath at $37^{\circ} \mathrm{C}$ with $1 \mathrm{mg} / \mathrm{ml}$ collagenase (type $1 \mathrm{~A}$ ), $50 \mu \mathrm{g} / \mathrm{ml}$ DNase and $50 \mu \mathrm{g} / \mathrm{ml}$ trypsin inhibitor in $250 \mathrm{ml}$ TC 199 Media containing $1 \mathrm{~g} / \mathrm{l}$ bovine serum albumin and $0 \cdot 1 \mathrm{~g} / \mathrm{l}$ L-glutamine. Preparations of purified Leydig cells were obtained by layering the collagenase-dispersed testicular cells onto discontinuous Percoll gradients supplemented with HBSS. The preparations were then centrifuged at $1500 \times \boldsymbol{g}$ for $15 \mathrm{~min}$ at $4{ }^{\circ} \mathrm{C}$ and the cells present at the $40-60 \%$ interface were collected as outlined previously (Raeside \& Renaud 1983). Cell viability was determined by trypan blue exclusion. The typical viability of Leydig cells after this procedure was greater than $90 \%$.

\section{Steroid extraction and analysis}

Conjugated steroids were separated from unconjugated steroids using methanol-primed Sep-Pak $\mathrm{C}_{18}$ solid-phase chromatography cartridges (Raeside \& Christie 1997). Sulfoconjugated steroids were hydrolyzed by incubating the conjugate fraction overnight in trifluoroacetic acid/ethyl acetate $(1 / 100 \mathrm{v} / \mathrm{v})$ at $45^{\circ} \mathrm{C}$. The hydrolyzed steroids were then purified by Sep-Pak $\mathrm{C}_{18}$ solid-phase chromatography.

Fat and extracted plasma samples were analyzed for $5 \alpha$-androstenone with an ELISA method, as described previously (Squires \& Lundström 1997). Media extracts were measured for DHEAS by radioimmunoassay (Schwarzenberger et al. 1993).

\section{Preparation of cytosol}

Frozen testes and liver samples were partially thawed and a $20 \%(\mathrm{w} / \mathrm{v})$ homogenate was prepared in $100 \mathrm{mM}$ Tris- $\mathrm{HCl}, 10 \mu \mathrm{M}$ EDTA, and $250 \mathrm{mM}$ sucrose at 
$\mathrm{pH} 7 \cdot 4$. Homogenates were centrifuged for $15 \mathrm{~min}$ at $10000 \times \boldsymbol{g}$ at $4{ }^{\circ} \mathrm{C}$ and the resulting supernatant was removed and centrifuged for $60 \mathrm{~min}$ at $105000 \times \boldsymbol{g}$ at $4{ }^{\circ} \mathrm{C}$. The supernatant (cytosol) was removed and stored at $-70{ }^{\circ} \mathrm{C}$. The protein content was determined using the Bradford protein assay (Bio-Rad Laboratories Ltd, Mississauga ON, Canada) using bovine serum albumin as a standard.

\section{Cytosolic sulfotransferase activity assay}

Sulfotransferase activity was assayed by the method of Matsui et al. (1993) using DHEA as a substrate. The incubation media contained $100 \mathrm{mM}$ Tris/HCl, $100 \mu \mathrm{M}$ EDTA, $100 \mu \mathrm{M}$ PAPS, $10 \mathrm{mM} \mathrm{MgCl}_{2}$ and $50 \mu \mathrm{M}\left[{ }^{3} \mathrm{H}\right]$ DHEA (approx. $0 \cdot 01-0 \cdot 05 \mu \mathrm{Ci} / \mathrm{nmol}$ ) in a final volume of $500 \mu \mathrm{l}$ at $\mathrm{pH} 7 \cdot 4$. Incubations were carried out at $37^{\circ} \mathrm{C}$ for $15 \mathrm{~min}$ with $25 \mu \mathrm{g}$ total cytosolic protein. Blank values were obtained with incubations without PAPS. The reactions were terminated by the addition of $100 \mu \mathrm{l} 0.1 \mathrm{M} \mathrm{NaOH}$, followed by snap-freezing in liquid nitrogen. The samples were then immediately extracted by Sep-Pak $\mathrm{C}_{18}$ solid-phase chromatography, as described above. After extraction, $100 \mu \mathrm{l}$ aliquots of the unconjugated and conjugated fractions were subjected to liquid scintillation counting.

\section{Screening of a porcine cDNA RACE library and sequence analysis}

A rapid amplification of the $5^{\prime}$ and $3^{\prime}$ cDNA ends (RACE) library was constructed from $1 \mu \mathrm{g}$ total RNA from liver with the use of the Smart RACE cDNA amplification kit (BD Biosciences, Mississauga, ON, Canada) as described previously (Lin et al. 2004). The cDNA library was used as a template in the subsequent PCR screening of porcine Sult2A1. The first fragment of porcine Sult2A1 was amplified with primers designed from a porcine expressed sequence tag (Genbank Accession No. BI402591) related to reproductive function that was $82 \%$ homologous to human Sult $2 A 1$. To obtain the full-length porcine Sult2A1 cDNA, forward and reverse primers were designed based on the sequence obtained from the $5^{\prime}$ and $3^{\prime}$ RACE and used to amplify the full-length porcine Sult2A1 with either $5^{\prime}$ or 3' RACE cDNA as a template. The nucleotide sequence of the forward primer was 5' CACGAGGGGCAAA GAACT 3', and the reverse primer was 5' CATGT GCAAGGACAGGTGAG 3'. The PGR consisted of 35 cycles of denaturing for $1 \mathrm{~min}$ at $94^{\circ} \mathrm{C}$, annealing for $1 \mathrm{~min}$ at $63^{\circ} \mathrm{C}$, and extending for $1 \mathrm{~min}$ at $72^{\circ} \mathrm{C}$. A final extension step was performed for $10 \mathrm{~min}$ at $72^{\circ} \mathrm{C}$. Ten microlitres of the PCR product were analyzed by electrophoresis on a $1 \%$ agarose gel.
The PCR fragments were ligated into a pGEM-T Easy Vector System (Promega, Madison, WI, USA), and then transformed into competent DH5 $\alpha$ cells. Plasmid DNAs were purified and sequenced.

\section{Isolation of total RNA and reverse transcription-PCR}

A total of $100 \mathrm{mg}$ of testes and liver tissue was homogenized in $1 \mathrm{ml}$ Tri-Reagent (Sigma-Aldrich Ltd) and total RNA was isolated according to the manufacturer's instructions. Approximately $0.5 \mu \mathrm{g}$ total RNA was used to synthesize first strand cDNA using Superscript II RNase $\mathrm{H}^{-}$Reverse Transcriptase (Invitrogen Life Technologies), following the manufacturer's instructions. The RT reaction was performed at $25^{\circ} \mathrm{C}$ for $10 \mathrm{~min}, 42{ }^{\circ} \mathrm{C}$ for $50 \mathrm{~min}$, followed by a 15 min incubation at $70^{\circ} \mathrm{C}$. First-strand cDNAs were stored at $4{ }^{\circ} \mathrm{C}$ until single-strand conformational polymorphism (SSCP) or RT-PCR analysis.

Following the reverse transcription reaction, $2.5 \mu \mathrm{l}$ of the first strand cDNA were used as a template for PCR.

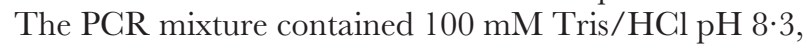
$500 \mathrm{mM} \mathrm{KCl}, 11 \mathrm{mM} \mathrm{MgCl}, 0 \cdot 1 \%$ gelatin, $0 \cdot 2 \mathrm{mM}$ dNTP, 2.5 U Red Taq polymerase (Sigma-Aldrich Ltd), and $0.4 \mathrm{mM}$ of the porcine SULT2Al forward and reverse primers. The PGR profile was the same as stated above.

\section{SSCP analysis}

The PCR products from both testicular and hepatic cDNAs were digested into fragments (230, 345 and $459 \mathrm{bp}$ ) with XmiI and SacI restriction endonucleases (MBI Fermentas, Burlington, ON, Canada) for $3 \mathrm{~h}$ at $37^{\circ} \mathrm{C}$. A total of $7 \mu \mathrm{l}$ of the digested cDNA fragments was combined with $13 \mu$ l loading buffer $(10 \%$ sucrose, $0.01 \%$ Bromophenol blue, 0.01\% Xylene cyanol FF). The samples were then denatured at $100{ }^{\circ} \mathrm{C}$ for $5 \mathrm{~min}$, followed by immediate cooling on ice. The samples were then loaded onto a $10 \%$ polyacrylamide gel. Electrophoresis was carried out for $17 \mathrm{~h}$ at $160 \mathrm{~V}$ using a $130 \times 160 \times 1 \mathrm{~mm}$ vertical unit (Bio-Rad Laboratories Ltd) maintained at $15^{\circ} \mathrm{C}$ with a refrigerated circulating water bath. After electrophoresis, the gels were silver stained to resolve the individual banding patterns. Polymorphisms were verified by sequencing all of the samples.

\section{Western blot analysis}

A total of $15 \mu \mathrm{g}$ and $50 \mu \mathrm{g}$ of testicular and hepatic cytosolic proteins respectively were resolved on $12 \%$ polyacrylamide gels and transferred to Hybond-C nitrocellulose membranes (Amersham Biosciences, Baie d'Urfè, QG, Canada), according to the method outlined by Laemmli (1970). Immunoreactive porcine SULT2A1 protein was determined using a commercially available 
polyclonal antibody to human SULT2A1 (MBL International Co., Watertown, MA, USA) diluted 1:5000. The secondary antibody was a 1:2000 dilution of donkey anti-rabbit IgG coupled to horseradish peroxidase (Amersham Biosciences). Equal loading of protein samples was verified following transfer by Coomassie Blue staining of the membranes. Blots were visualized by chemiluminescence detection and subsequently quantified by densitometry.

\section{Real-time PCR}

Real-time PCR amplification was performed using a Copeheid Smart Cycler System (Fisher Scientific, Toronto, ON, Canada). Forward and reverse primers were designed based on the porcine Sult2A1 sequence. The forward primer $5^{\prime}$ CGATGGGAGACAAGGAG AAC 3', and reverse primer 5' CATGACGTGGAAG GAGCTGT 3' amplified a product of $155 \mathrm{bp}$ in length at an annealing temperature of $60^{\circ} \mathrm{C}$. The QuantiTect SYBR Green PCR Amplification kit (Qiagen, Mississauga, ON, Canada) was used for the real-time quantification of the PCR products. The real-time PCR reaction consisted of $2.5 \mu \mathrm{l} c \mathrm{DNA}$, and $20 \mu \mathrm{M}$ of the forward and reverse primers, in a total volume of $25 \mu \mathrm{l}$. As an internal control, the hypoxanthine-guanine phosphoribosyltransferase (HPRT) gene was amplified for each real-time PGR reaction. HPRT amplification included the forward primer 5' CTTTGCTGACCTG CTGGATT 3', and reverse primer 5' CTTGACGAA GGAAAGCAAGG 3', which amplified a product of $232 \mathrm{bp}$ in length. Relative quantification of mRNA levels between animals with different levels of SULT2A1 protein was analyzed by the $\triangle \mathrm{Ct}$ method (Livak \& Schmittgen 2001) using the average $\triangle \mathrm{Ct}$ of the low SULT2A1 protein group as the calibrator.

\section{Identification of nuclear receptors involved in regulating SULT2A1}

To further understand the molecular mechanisms that control SULT2A1 gene transcription, various nuclear receptor ligands were evaluated for their ability to induce SULT2A1 activity in Leydig cells. Aliquots of re-suspended Leydig cells $\left(1 \times 10^{6}\right.$ cells $\left./ \mathrm{ml}\right)$ in TC 199 Media mixture were plated in 24-well plates. The Leydig cells were then treated with various nuclear receptor ligands as outlined in the figure legends in less than $0.5 \%$ DMSO vehicle and incubated at $37{ }^{\circ} \mathrm{C}$ in $95 \%$ air and $5 \% \mathrm{CO}_{2}$ for $24 \mathrm{~h}$.

After the 24-h incubation period, the media were aspirated and approximately 10000 c.p.m. $\left[{ }^{3} \mathrm{H}\right]$ DHEA $(0 \cdot 01-0 \cdot 05 \mu \mathrm{Ci} / \mathrm{nmol})$ were added to each well in a final volume of $1 \mathrm{ml}$ TC 199 Media. The cells were incubated for $4 \mathrm{~h}$ and the media were removed and immediately extracted by Sep-Pak $\mathrm{C}_{18}$ solid-phase chromatography, as described above. Sulfotransferase activity was assayed by measuring the conversion of $\left[{ }^{3} \mathrm{H}\right] \mathrm{DHEA}$ (free) to $\left[{ }^{3} \mathrm{H}\right]$ DHEAS (conjugate) fractions by liquid scintillation counting. The results from the different Leydig cell preparations were normalized as a percentage of the average results from the control incubations from each cell preparation.

\section{Statistical analyses}

Pearson correlation coefficients were calculated for the following measures: (1) SULT2Al activity vs plasma concentrations of sulfoconjugated $5 \alpha$-androstenone, (2) SULT2A1 activity vs fat concentrations of $5 \alpha$ androstenone (SAS 8.2, SAS Institute, Cary, NC, USA). Correlations were considered statistically significant at $P \leq 0 \cdot 05$. Differences in SULT2Al activity, protein and mRNA levels between high and low boar taint pigs were analyzed by Student's $t$-test (SAS $8 \cdot 2$, SAS Inst. Inc.). Differences in SULT2A1 activity following treatment with nuclear receptor ligands were analyzed by ANOVA using the Dunnet post-hoc test (SAS 8·2, SAS Inst. Inc.).

\section{Results}

\section{Relationship between SULT2A1 activity and $5 \alpha$-androstenone in plasma}

A strong positive correlation $(r=0.66 ; P<0.01)$ was observed between the testicular activity of SULT2A1 and plasma concentrations of $5 \alpha$-androstenone in the sulfoconjugate fraction (Fig. 1A); however, this relationship was not as strong $(r=0.13 ; P<0 \cdot 01)$ with respect to hepatic SULT2A1 activity (Fig. 1B). In terms of testicular SULT2A1 activity, animals with the highest sulfotransferase activity had the highest concentrations of sulfated $5 \alpha$-androstenone in peripheral plasma, with concentrations as high as $57 \mathrm{ng} / \mathrm{ml}$. In addition, these animals also had the lowest concentrations of unconjugated $5 \alpha$-androstenone, at levels below $9 \mathrm{ng} / \mathrm{ml}$ (data not shown).

There was a negative correlation $(r=-0 \cdot 57 ; P<0 \cdot 01)$ between testicular SULT2A1 activity and the concentrations of $5 \alpha$-androstenone in fat (Fig. 2A). All of the animals with fat $5 \alpha$-androstenone concentrations less than $0.5 \mu \mathrm{g} / \mathrm{g}$ had correspondingly high SULT2Al activities. This relationship was also observed to a lesser extent $(r=-0.31 ; \quad P<0.05)$ for hepatic SULT2A1 activity (data not shown). In order to examine further the relationship between SULT2Al activity and $5 \alpha$-androstenone accumulation in fat, animals were separated into two groups based on fat $5 \alpha$-androstenone concentrations either above or below the limit of $0 \cdot 5 \mu \mathrm{g} / \mathrm{g}$. This limit has been determined to be relevant to consumer satisfaction in the detection of taint 

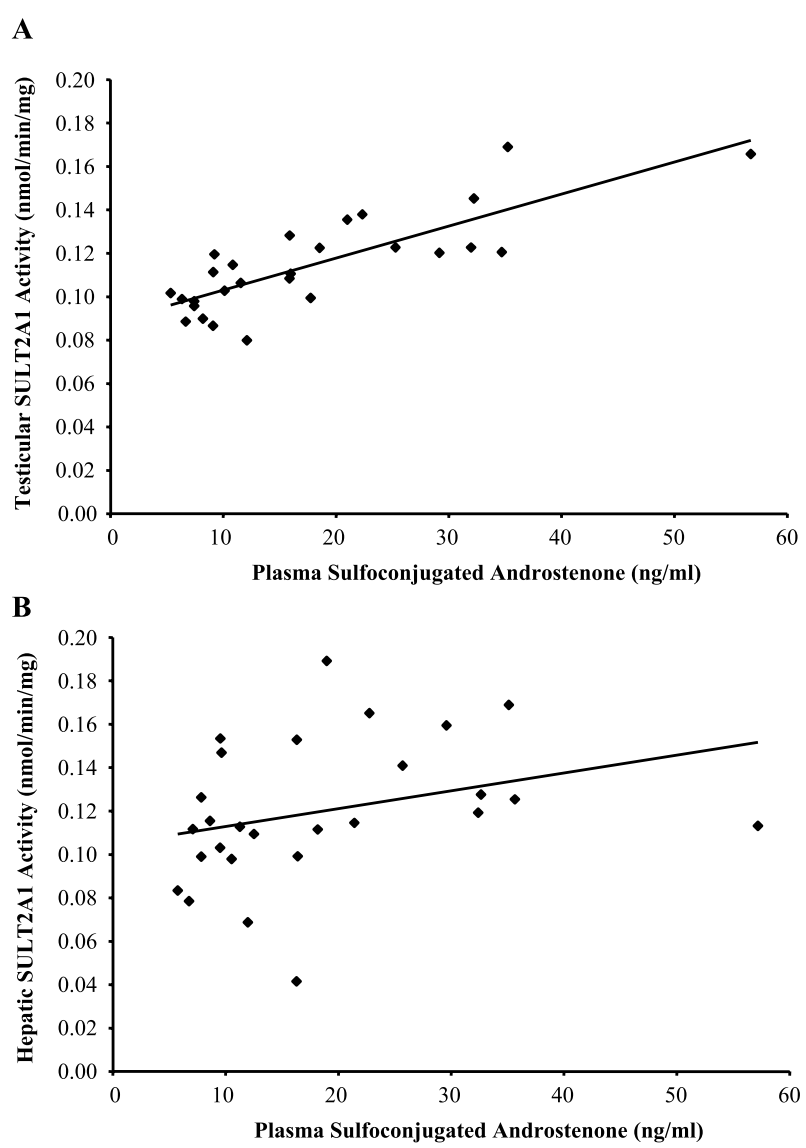

Figure 1 Positive relationship between testicular and hepatic SULT2A1 activity and plasma levels of sulfoconjugated $5 \alpha$-androstenone. Cytosolic testicular (A) and hepatic (B) SULT2A1 activities were compared with circulating plasma levels of sulfoconjugated $5 \alpha$-androstenone. Analysis of 27 Yorkshire boars aged $175 \pm 6$ days showed a positive relationship $(r=0.66(\mathrm{~A})$ and $r=0.13(\mathrm{~B}), P<0.01)$ to plasma sulfoconjugated $5 \alpha$-androstenone.

(Bonneau et al. 2000). Both testicular and hepatic SULT2A1 activities (Fig. 2B) were significantly lower $(P<0.01)$ in animals with fat $5 \alpha$-androstenone concentrations higher than $0.5 \mu \mathrm{g} / \mathrm{g}$.

\section{Isolation and sequence characterization of porcine Sult2A1 cDNA}

The nucleotide sequence of the porcine Sult2A1 cDNA (Genbank Accession No. DQ172907) was 1019 bp long and contained a $855 \mathrm{bp}$ long open reading frame (ORF), which encodes for 285 amino acids (Fig. 3). The porcine Sult2A1 ORF displayed $82 \%$ homology to human Sult $2 A 1$ and $84 \%$ and $85 \%$ homology to mouse and rat hydroxysteroid sulfotransferase respectively. The deduced amino acid sequence for porcine SULT2A1 had $81 \%$ homology to human SULT2A1, and $80 \%$
$\mathbf{A}$

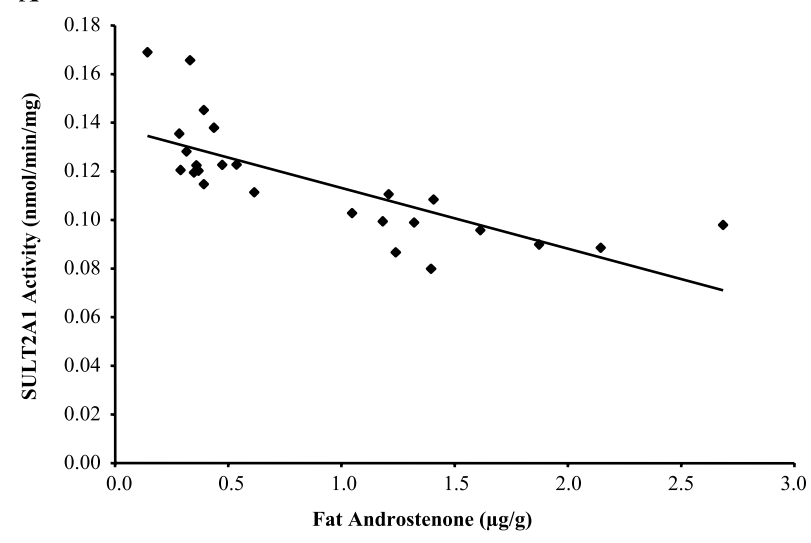

B

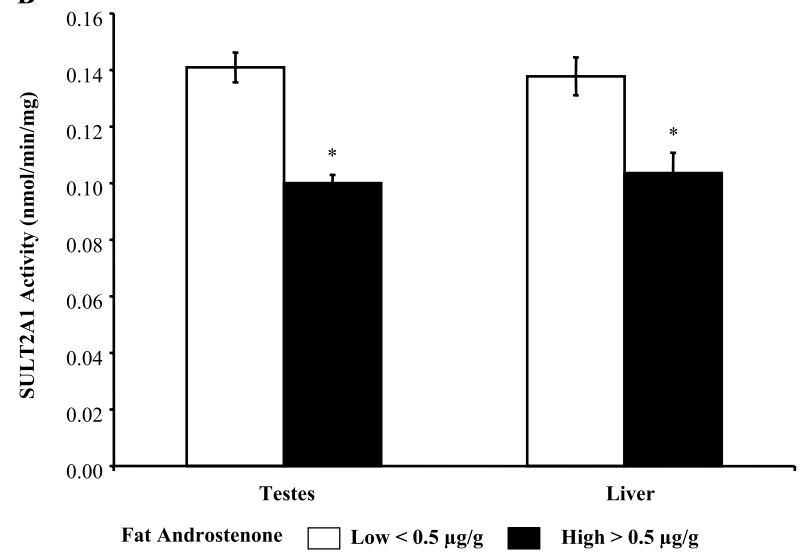

Figure 2 Negative relationship between testicular and hepatic SULT2A1 activity and $5 \alpha$-androstenone accumulation in fat. Cytosolic testicular (A) SULT2A1 activity was negatively related $(r=-0.57, P<0.01)$ to fat levels of $5 \alpha$-androstenone as determined in 175 \pm 6 -day-old Yorkshire boars $(n=27)$. (B) Boars were divided into low $(<0.5 \mu \mathrm{g} / \mathrm{g}$; open bars) or high ( $>0.5 \mu \mathrm{g} / \mathrm{g}$; solid bars) fat $5 \alpha$-androstenone levels for comparison with testes and liver SULT2A1 activity. Analysis showed a significantly $\left({ }^{*} P<0.01\right)$ lower level of SULT2A1 activity in boars with high fat $5 \alpha$-androstenone in both testes and liver. Values are presented as means \pm S.E. $(n=13)$.

homology to both mouse and rat hydroxysteroid sulfotransferase. In humans, Gly248, Val249, Ser250, Gly251, Asp252, Trp253, and Lys254 are reported to be the PAPS binding site for SULT2A1. In the porcine sequence, Gly248, Gly251, Asp252, Trp253, and Lys254 are conserved (Fig. 4).

\section{SULT2A1 genetic polymorphisms}

SSCP was used to scan for genetic polymorphisms in the porcine Sult2A1 coding region from both testicular and liver samples. Three different types of banding patterns were detected (Fig. 5). Sequence analysis showed that the observed SSCP banding patterns corresponded to a mutation from a cytosine to a thymine within the coding 


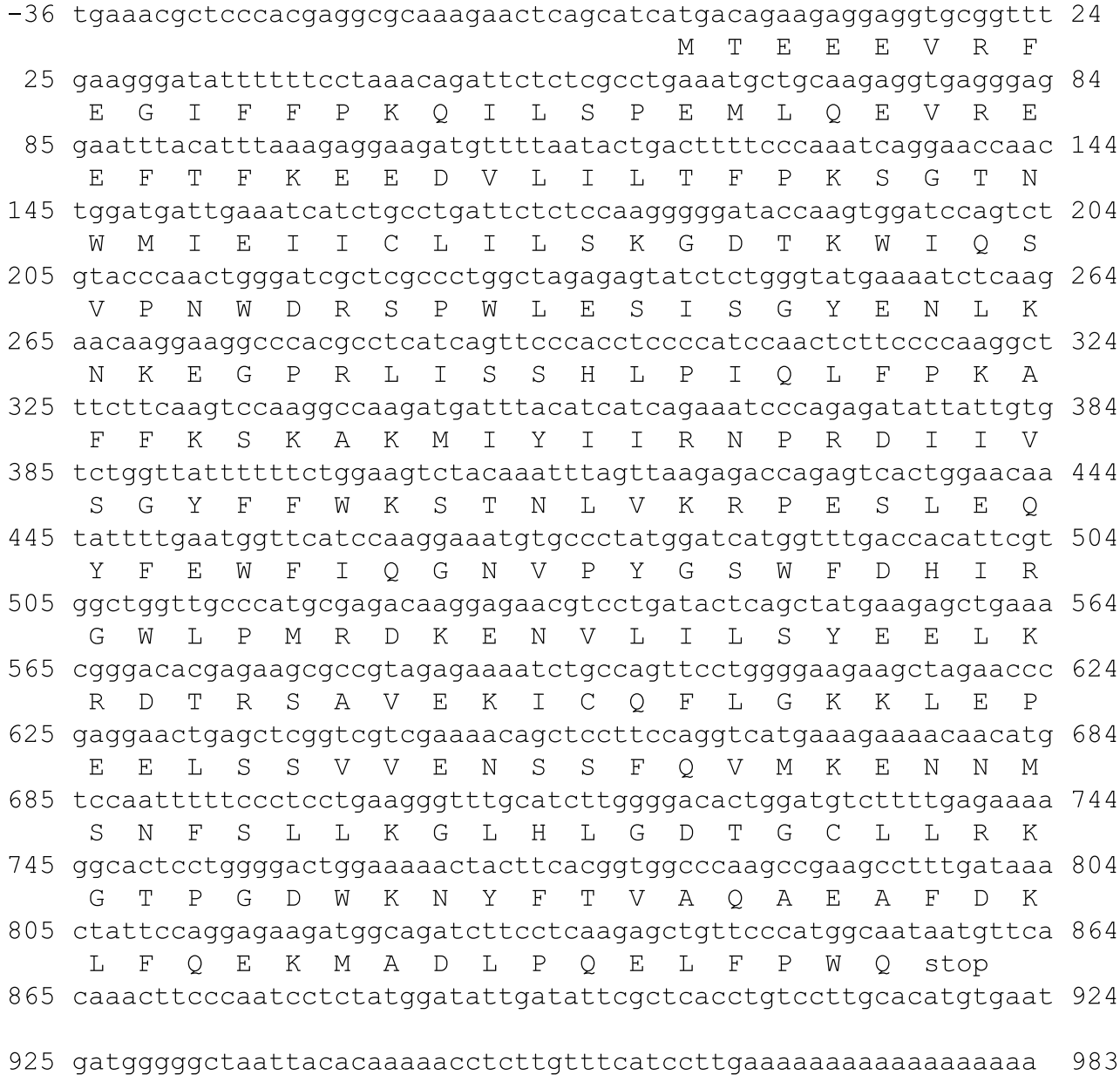

Figure 3 Porcine SULT2A1 cDNA nucleotide and deduced amino acid sequences. region at bp position 166 . This mutation did not cause a change in amino acid sequence and is therefore a silent mutation that is not directly associated with SULT2A1 activity.

\section{Comparison of SULT2A1 levels and $5 \alpha$-androstenone accumulation in fat}

The lack of functional polymorphisms within the coding region warranted investigation into whether the observed variation in SULT2Al activity was due to individual differences in the amount of SULT2Al protein that is produced. Western blot analysis determined that the differences in SULT2A1 activity were due to differences in the levels of SULT2A1 protein; animals with low SULT2A1 activity had low levels of both testicular and hepatic SULT2A1 protein. Figure 6 demonstrates the positive correlation $(r=0.53 ; P<0 \cdot 01)$ between the testicular level of SULT2A1 protein and enzyme activity. A similar relationship was observed with hepatic levels of
SULT2A1 (data not shown); however, the relationship was not as strong $(r=0 \cdot 22 ; P<0 \cdot 05)$. In addition, the concentration of $5 \alpha$-androstenone in the sulfoconjugate fraction of the plasma was positively correlated with testicular SULT2A1 protein $(r=0.42 ; \quad P<0 \cdot 01)$ and hepatic SULT2A1 protein $(r=0 \cdot 14 ; P<0 \cdot 01)$.

The levels of testicular and hepatic SULT2A1 protein as related to $5 \alpha$-androstenone accumulation in fat demonstrated a similar trend for SULT2Al activity, with animals showing high levels of $5 \alpha$-androstenone in fat having significantly lower levels $(P<0 \cdot 001)$ of total SULT2A1 protein (Fig. 7).

\section{Comparison of SULT2A1 protein and mRNA expression levels}

In order to determine whether the difference in SULT2A1 protein expression is regulated at the transcriptional level, quantitative real-time PCR was performed to measure the levels of Sult2A1 mRNA. 


\section{Porcine 2A1 MTEEEVRFEGIFFPKOILSPEMLOEVREEFTFKEEDVLILTFPKSGTNWMTEIICLIL Human 2A1 MSDDFLWFEGIAFPTMGFRSETLRKVRDEFVIRDEDVIILTYPKSGTNWLAEILCLMH}

$\begin{array}{lll} & 59 & 116 \\ \text { Porcine } & \text { 2A1 } & \text { SKGDTKWIQSVPNWDRSPWLESISGYENLKNKEGPRLISSHLPIQLFPKAFFKSKAKM } \\ \text { Human } & \text { 2A1 } & \text { SKGDAKWIQSVPIWERSPWVESEIGYTALSETESPRLFSSHLPIQLFPKSFFS SKAKV }\end{array}$

117

174

Porcine 2A1 IYIIRNPRDIIVSGYFFWKSTNLVKRPESLEQYFEWFIQGNVPYGSWFDHIRGWLPMR

Human 2A1 IYLMRNPRDVLVSGYFFWKNMKFIKKPKSWEEYFEWFCQGTVVYGSWFDHIHGWMPMR

$\begin{array}{lll} & 175 & 232 \\ \text { Porcine } & \text { 2A1 } & \text { DKENVLILSYEELKRDTRSAVEKICQFLGKKLEPEELSSVVENSSFQVMKENNMSNFS } \\ \text { Human } & \text { 2A1 } & \text { EEKNFLLLSYEELKQDTGRTIEKICQFLGKTLEPEELNLILKNSSFQSMKENKMSNYS }\end{array}$

$233 \quad 285$

Porcine 2A1 LLKGLHLGDTGCLLRKGF GDWK NYFTVAQAEAFDKLFQEKMADLPQELFPWQ

Human 2A1 LLSVDYVVDKAQLLRKGJS GDWKNHFTVAQAEDFDKLFQEKMADLPRELFPWE

Figure 4 Alignment of the amino acid sequence of human and porcine SULT2A1. The alignment of the 285 amino acid sequence of human and porcine SULT2A1 is shown, demonstrating the $81 \%$ homology (shaded) and conservation of the PAPS binding site (boxed).

Relative quantification revealed that the expression of the Sult2A1 gene was increased $2 \cdot 8$-fold $(P<0 \cdot 01)$ in animals with $1.5 \pm 0 \cdot 2$ - and $1.7 \pm 0 \cdot 2$-fold increases in testicular and liver SULT2A1 protein levels $(P<0 \cdot 05)$ relative to animals with low levels of the protein.

\section{Identification of nuclear receptors involved in regulating SULT2A1}

To further understand the transcriptional regulation of testicular SULT2A1, primary isolated Leydig cells were incubated with various nuclear receptor ligands for $24 \mathrm{~h}$ prior to the determination of SULT2A1 activity. As seen in Fig. 8, SULT2A1 activity was increased by treatment with some of the ligands to CAR, PXR and FXR. Of the CAR inducers, only phenytoin resulted in a significant increase in SULT2A1 activity $(P<0 \cdot 05)$. Rifampicin, a ligand of human and pig PXR (Moore et al. 2002), significantly increased $(P<0 \cdot 05)$ SULT2A1 activity. The glucocorticoid receptor (GR) ligand, dexamethasone, did not affect SULT2Al activity, whereas treatment with the FXR/PXR ligand, lithocholic acid, resulted in an increase in SULT2A1 activity $(P<0 \cdot 05)$.

\section{Discussion}

The extent to which $5 \alpha$-androstenone accumulates in fat is influenced by the amount of unconjugated steroid that is present in the circulation. Differences in the ability to sulfoconjugate $5 \alpha$-androstenone will affect the level of unconjugated steroid that is available to accumulate in fat. The levels of sulfoconjugated 16-androstene steroids present in the circulation are a result of the balance between the capacity for testicular steroidogenesis, sulfoconjugation, and metabolic clearance. The results of this study show that the concentration of sulfoconjugated $5 \alpha$-androstenone in the peripheral plasma is correlated with testicular SULT2Al activity $(r=0 \cdot 66)$ and to a lesser extent to hepatic SULT2Al activity $(r=0 \cdot 13)$. Furthermore, we show that treatment with ligands for the nuclear receptors CAR, PXR and possibly FXR can stimulate SULT2Al activity in isolated Leydig cells. Together, these results further clarify the magnitude of testicular sulfoconjugation of androstenone and the role of SULT2A1, and suggest the possible control of porcine SULT2A1 expression by nuclear receptors.

High levels of steroid sulfotransferase enzymes are present in the boar testis, which are responsible for the large proportion of sulfoconjugated steroids that are secreted from this organ (Tan \& Raeside 1980, Raeside \& Renaud 1983, Raeside et al. 1989). The liver also sulfoconjugates the 16-androstene steroids, but to a lesser extent than the testis (Sinclair \& Squires 2005, Sinclair et al. 2005). Our present results indicate that animals with high concentrations of $5 \alpha$-androstenone in fat had significantly lower SULT2A1 activity in both testis and liver; thus more of the unconjugated form of the steroid will be available to deposit into the adipose tissue to contribute to boar taint.

The relationship between SULT2A1 activity and the accumulation of $5 \alpha$-androstenone in fat warranted investigation at the molecular level, as genetic polymorphisms within the Sult2A1 gene may account for the 


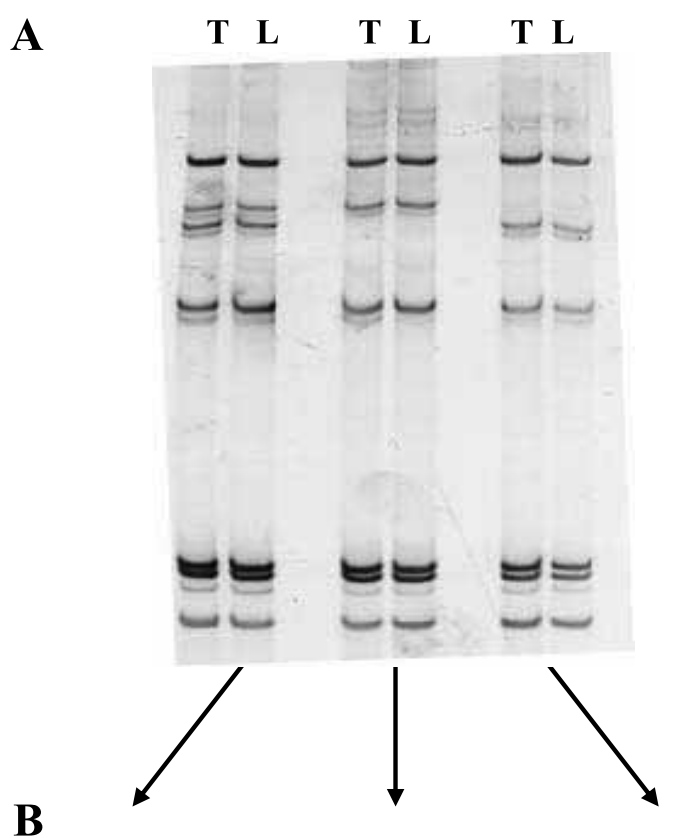

G C N T G

G C T T G

G C C T G
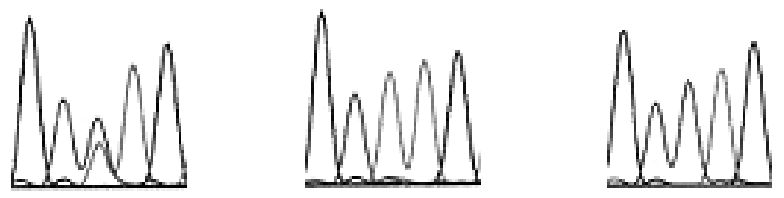

Figure 5 Identification of a genetic polymorphism in the porcine SULT2A1 gene. A representative silver stained SSCP gel (A) and corresponding sequence analysis (B) is shown demonstrating heterozygotes and homozygotes in both testicular ( $\mathrm{T}$ ) and liver (L) tissue samples for a T/C polymorphism at the $166 \mathrm{bp}$ position.

differences observed in enzyme activity. In order to test this hypothesis, the cDNA sequence for porcine Sult2A1 was determined and found to be highly homologous to its orthologous human, mouse and rat genes. These findings lead to the conclusion that the putative Sult2A1 is in fact porcine Sult2A1.

Human SULT2A1 has been mapped to chromosome 19q13.3 (Luu-The et al. 1995, Otterness et al. 1995), which is homologous with porcine chromosome $6 \mathrm{q} 11$, 21 and chromosome $7 \mathrm{p} 12$. The homology to porcine chromosome 7 is of interest, as a quantitative trait loci for fat $5 \alpha$-androstenone levels has been mapped to this location (Quintanilla et al. 2003, Tanaka et al. 2003).

SULT2A 1 is involved in the biotransformation of many steroid hormones, neurotransmitters, bile acids, drugs and xenobiotics. Therefore, identification of genetic differences that cause changes in enzyme activity may be crucial in determining the individual response to

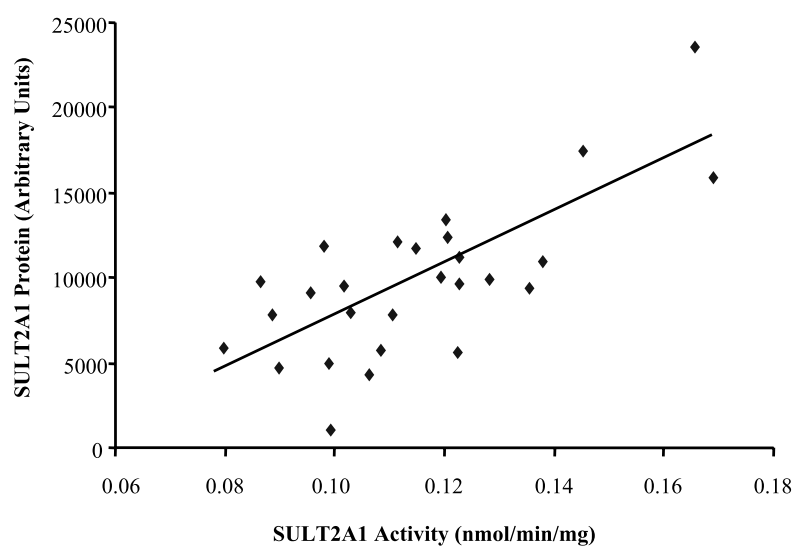

Figure 6 Positive relationship between testicular SULT2A1 protein and activity levels. SULT2A1 activity was determined in testis cytosol from $175 \pm 6$-day-old Yorkshire boars $(n=27)$ and compared with the corresponding SULT2A1 protein levels as determined by western blotting and densitometry. Analysis revealed a significant positive correlation $(r=0.53, P<0.01)$ between protein and activity levels.

specific compounds. In humans, substantial efforts have been made to detect genetic polymorphisms in SULT2A1 due to its involvement in cardiovascular diseases and cancer (LaCroix et al. 1992, Stahl et al. 1992, Shibutani et al. 1998). Polymorphisms within the human Sult2A1 gene have been observed in a number of studies (Igaz et al. 2002), some of which have resulted in reductions in the levels of both enzyme activity and protein levels (Thomae et al. 2002). However, despite the

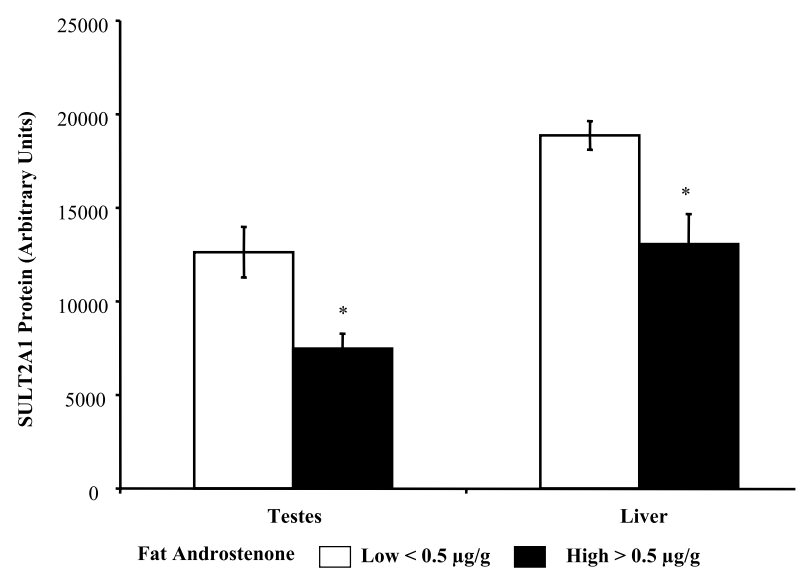

Figure 7 Increased levels of SULT2A1 protein are associated with lower levels of $5 \alpha$-androstenone accumulation in fat. Boars were divided into low $(<0.5 \mu \mathrm{g} / \mathrm{g}$; open bars) or high ( $>0.5 \mu \mathrm{g} / \mathrm{g}$; solid bars) fat $5 \alpha$-androstenone levels, and SULT2A1 protein levels in testes and liver as determined by densitometric analysis of western blots were compared. Analysis showed a significantly $\left({ }^{\star} P<0.001\right)$ higher level of SULT2A1 protein levels in boars with low fat $5 \alpha$-androstenone in both testes and liver. Values are presented as means \pm S.E. $(n=13)$. 


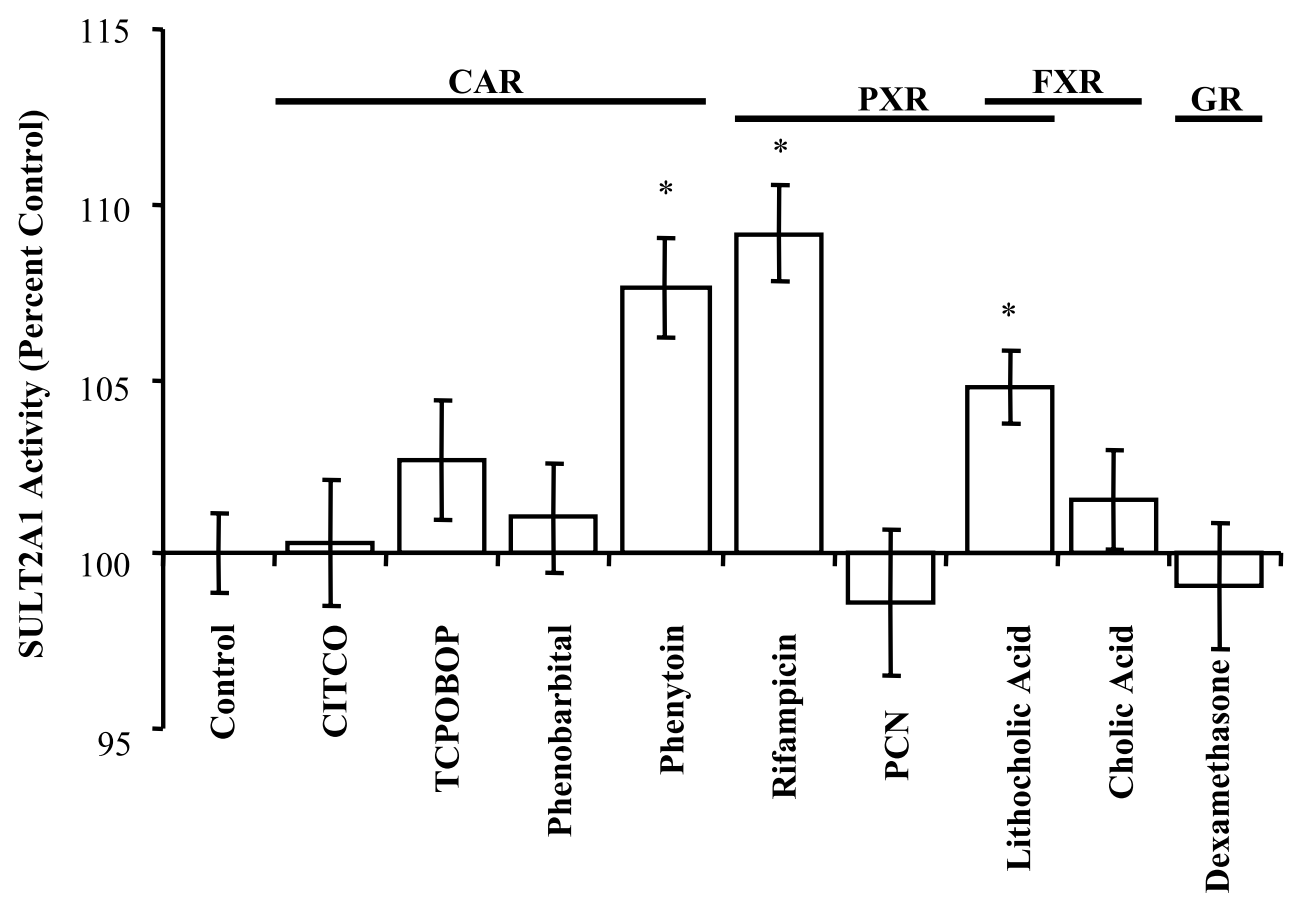

Figure 8 Effect of nuclear receptor ligands on SULT2A1 activity in porcine Leydig cells. Primary porcine Leydig cells were isolated from mature Yorkshire boars and the SULT2A1 activity was determined. Leydig cells were cultured in the presence of CITCO $(1 \mu \mathrm{M})$, TCPOBOP $(250 \mathrm{nM})$, phenobarbital $(2 \mathrm{mM})$, phenytoin $(50 \mu \mathrm{M})$, rifampicin $(10 \mu \mathrm{M}), \operatorname{PCN}(10 \mu \mathrm{M})$, lithocholic acid $(100 \mu \mathrm{M})$, cholic acid $(100 \mu \mathrm{M})$, and dexamethasone $(0.1 \mu \mathrm{M})$ for $24 \mathrm{~h}$. Treatments are grouped according to the nuclear receptor affected: constitutive androstane receptor (CAR), pregnane $X$ receptor (PXR), farnesoid $X$ receptor (FXR), and glucocorticoid receptor (GR). Values are presented as means $\pm S . E$. of 3 independent experiments with significant differences indicated $\left({ }^{\star} P<0.05\right)$.

fact that this enzyme is highly polymorphic, the mutation may not be functionally correlated to the activity or level of the protein levels. In the present study, there were no significant functional polymorphisms detected within the ORF of the porcine Sult2A1 gene. Therefore, differences in enzyme activity are not attributed to mutations within the coding region. After western blot analysis, it was determined that the differences observed in SULT2A1 activity were a result of differences in the amount of SULT2A1 protein that was expressed within the tissue. Animals with low SULT2A1 activity in testis and liver tissues had correspondingly low protein levels. This decrease in protein will therefore contribute to a decreased sulfoconjugation activity towards the 16-androstene steroids.

There are multiple regulatory mechanisms involved in controlling gene expression, many of which influence the level of functional protein. At the transcriptional level, alterations in receptor-dependent mechanisms or transcription factors could lead to differences in the amount of mRNA that is transcribed (Tsai \& O'Malley 1994). Post-transcriptional mechanisms such as mRNA stabilization can also play a significant role in determining the level of production of an end product (Day \& Tuite 1998). In addition, there are multiple processing events that operate at the translational and post-translational levels that could have an equal impact on the amount or stability of functional product. The results from the quantitative real-time PCR analysis suggest that the level of SULT2A1 production is regulated at the transcriptional level, as animals with high testicular $(1.5 \pm$ $0 \cdot 2$-fold) and liver $(1 \cdot 7 \pm 0 \cdot 2$-fold $)$ levels of SULT2A1 protein expressed $2 \cdot 8$-fold more mRNA for Sult $2 A 1$ than animals with low levels of the protein.

The molecular mechanisms that control SULT2A1 gene transcription have not been fully characterized. Chenodeoxycholic acid has been demonstrated to be a strong inducer of the rat SULT2Al gene (Makishima et al. 1999). This inducing effect is controlled, in part, by the bile acid-activated FXR (Song et al. 2001). Similarly, human SULT2A1 has been shown to be induced in response to various ligands for the PXR (Kliewer et al. 1998, Duanmu et al. 2002, Echchgadda et al. 2004). More recently, it has been determined that the CAR is also potentially involved in rodent SULT2A1 regulation (Saini et al. 2004). The results of this study suggest that the recently identified human CAR activator, phenytoin 
(Jackson et al. 2004), resulted in a significant increase in pig SULT2A1 activity, whereas CITCO (Maglich et al. 2003) and the CAR agonists TCBOPOP and phenobarbital did not affect SULT2A1 activity. While these classical inducers are known as potent rodent inducers, their influence on human gene expression is often absent or attenuated in comparison with rodents (Moore et al. 2002). Similarly, the treatment of Leydig cells with the PXR ligands rifampicin and PCN demonstrated that only rifampicin resulted in a significant increase in SULT2A1 activity. This observation is consistent with the results of Moore et al. (2002) who demonstrated in a reporter assay system that rifampicin is a potent activator of pig PXR. However, PCN, a PXR inducer in mouse, rabbit, and monkey, does not activate either human or pig PXR. Furthermore, dexamethasone, which can affect CAR and PXR both directly and indirectly (Pascussi et al. 2000a,b), did not increase SULT2A1 activity of Leydig cells at $10^{-7} \mathrm{M}$ within the $24 \mathrm{~h}$ treatment period. In comparison with these exogenous ligands, lithocholic acid, a bile acid that acts through the FXR, induced pig SULT2Al activity. However, Moore et al. (2002) demonstrated that lithocholic acid, but not cholic acid, may also activate porcine PXR. Together, these data suggest the importance of CAR, PXR, and potentially FXR in the regulation of SULT2Al activity. This does not exclude the involvement of other orphan receptors in the regulation of pig SULT2A1 not investigated here. For instance, both steroidogenic factor 1 (SF1) and GATA6 have been shown to regulate the transcription of human Sult2A1 (Saner et al. 2005). Furthermore, this study also highlights the similarity in responsiveness of nuclear receptors of human and pig compared with rodent species. Differences in the level of gene transcription of Sult2A1 may be due to individual differences in the activation of these receptors or differences in the proximal promoter region of the gene that contains the recognition sequences for these transcription factors. However, the $5^{\prime}$ - proximal promoter region of porcine Sult2A1 gene has not yet been characterized.

In summary, the accumulation of $5 \alpha$-androstenone in fat is influenced by the individual capacity for sulfoconjugation. SULT2A1 has been identified to be the key enzyme involved in the sulfoconjugation of the 16-androstene steroids. After isolation of the porcine Sult2A1 cDNA, it was determined that differences in enzyme activity were not the result of genetic polymorphisms in the coding region. The proportion of sulfoconjugated $5 \alpha$-androstenone present in the circulation is dependent on the level of SULT2A1 protein that is expressed and thus its relative activity. The finding that animals with low levels of SULT2A1 have resulting higher levels of $5 \alpha$-androstenone concentrations in fat suggests that sulfoconjugation plays a vital role in regulating the level of unconjugated or 'free' steroid that is capable of accumulating in adipose tissue. Based on these results, SULT2A1 is a potential candidate gene for the development of genetic markers for selecting animals with low boar taint. Further investigation into the transcriptional regulation of SULT2A1 is required to confirm this possible new and appealing application.

\section{Acknowledgements}

This work was supported by funding from the Natural Sciences and Engineering Research Council of Canada (NSERG) and the Ontario Ministry of Agriculture and Food (OMAF). The authors declare that there is no conflict of interest that would prejudice the impartiality of this scientific work.

\section{References}

Bonneau M, Walstra P, Claudi-Magnussen C, Kempster AJ, Tornberg E, Fischer K, Diestre A, Siret F, Chevillon P, Claus R, Dijksterhuis GB, Punter P, Matthews KR, Agerhem H, Béauge MP, Oliver MA, Gisper M, Weiler U, von Seth G, Leask H, Font I, Furnols M, Homer DB \& Cook GL 2000 An international study on the importance of androstenone and skatole for boar taint. IV. Simulation studies on consumer dissatisfaction with entire male pork and the effect of sorting out carcasses on the slaughter line, main conclusions and recommendations. Meat Science 54 285-295.

Comer KA, Falany JL \& Falany CN 1993 Cloning and expression of human liver dehydroepiandrosterone sulphotransferase. Biochemical fournal 289 233-240.

Day DA \& Tuite MF 1998 Post-transcriptional gene regulatory mechanisms in eukaryotes: an overview. Fournal of Endocrinology $157361-371$.

Duanmu Z, Locke D, Smigelski J, Wu W, Dahn MS, Falany CN, Kocarek TA \& Runge-Morris M 2002 Effects of dexamethasone on aryl (SULT1A1)- and hydroxysteroid (SULT2A1)sulfotransferase gene expression in primary cultured human hepatocytes. Drug Metabolism and Disposition 30 997-1004.

Echchgadda I, Song CS, Oh TS, Cho SH, Rivera OJ \& Chatterjee B 2004 Gene regulation for the senescence marker protein DHEA-sulfotransferase by the xenobiotic-activated nuclear pregnane X receptor (PXR). Mechanical Ageing Development $125733-745$.

Gasparini FJ, Hochberg RB \& Lieberman S 1976 Biosynthesis of steroid sulfates by the boar testes. Biochemistry 15 3969-3975.

Hobkirk R 1985 Steroid sulfotransferases and steroid sulfate sulfatases: characteristics and biological roles. Canadian Fournal of Biochemistry and Cell Biology 63 1127-1144.

Hobkirk R, Renaud R \& Raeside JI 1989 Partial characterization of steroid sulfohydrolase and steroid sulfotransferase activities in purified porcine Leydig cells. Fournal of Steroid Biochemistry 32 387-392.

Igaz P, Pap E, Patocs A, Falus A, Tulassay Z \& Racz K 2002 Genomics of steroid hormones: in silico analysis of nucleotide sequence variants (polymorphisms) of the enzymes involved in the biosynthesis and metabolism of steroid hormones. Fournal of Steroid Biochemistry and Molecular Biology 82 359-367.

Jackson JP, Ferguson SS, Moore R, Negishi M \& Goldstein JA 2004 The constitutive active/androstane receptor regulates phenytoin induction of Cyp2c29. Molecular Pharmacology 65 1397-1404. 
Jakoby WB, Sckura RD, Lyon ES, Marcus CJ \& Wang JL 1980 Sulfotransferases. In Sulfotransferases, pp 1999-1228. Ed. WB Jakoby. New York: Academic Press.

Kliewer SA, Moore JT, Wade L, Staudinger JL, Watson MA, Jones SA, McKee DD, Oliver BB, Willson TM, Zetterstrom RH, Perlmann T \& Lehmann JM 1998 An orphan nuclear receptor activated by pregnanes defines a novel steroid signaling pathway. Cell 92 73-82.

LaCroix AZ, Yano K \& Reed DM 1992 Dehydroepiandrosterone sulfate, incidence of myocardial infarction, and extent of atherosclerosis in men. Circulation 86 1529-1535.

Laemmli UK 1970 Cleavage of structural proteins during the assembly of the head of bacteriophage T4. Nature 227 680-685.

Lin Z, Lou Y \& Squires JE 2004 Molecular cloning and functional analysis of porcine SULT1Al gene and its variant: a single mutation SULT1Al causes a significant decrease in sulfation activity. Mammalian Genome 15 218-226.

Livak KJ \& Schmittgen TD 2001 Analysis of relative gene expression data using real-time quantitative PCR and the 2(-delta delta $\mathrm{C}(\mathrm{T})$ ) method. Methods 25 402-408.

Luu-The V, Dufort I, Paquet N, Reimnitz G \& Labrie F 1995 Structural characterization and expression of the human dehydroepiandrosterone sulfotransferase gene. DNA Cell Biology 14 511-518.

Maglich JM, Parks DJ, Moore LB, Collins JL, Goodwin B, Billin AN, Stoltz CA, Kliewer SA, Lambert MH, Willson TM \& Moore JT 2003 Identification of a novel human constitutive androstane receptor (CAR) agonist and its use in the identification of CAR target genes. Fournal of Biological Chemistry 278 17277-17283.

Makishima M, Okamoto AY, Repa JJ, Tu H, Learned RM, Luk A, Hull MV, Lustig KD, Mangelsdorf DJ \& Shan B 1999 Identification of a nuclear receptor for bile acids. Science $2841362-1365$.

Matsui M, Takahashi M \& Homma H 1993 Inhibition of rat liver hydroxysteroid sulfotransferase activity by alkylamines. Biochemistry and Pharmacology 46 465-470.

Moore LB, Maglich JM, McKee DD, Wisely B, Willson TM, Kliewer SA, Lambert MH \& Moore JT 2002 Pregnane X receptor (PXR), constitutive androstane receptor (CAR), and benzoate $\mathrm{X}$ receptor (BXR) define three pharmacologically distinct classes of nuclear receptors. Molecular Endocrinology 16 977-986.

Otterness DM, Mohrenweiser HW, Brandriff BF \& Weinshilboum RM 1995 Dehydroepiandrosterone sulfotransferase gene (STD): localization to human chromosome band $19 \mathrm{q} 13 \cdot 3$. Cytogenetics and Cell Genetics 70 45-47.

Pascussi JM, Drocourt L, Fabre JM, Maurel P \& Vilarem MJ $2000 a$ Dexamethasone induces pregnane $\mathrm{X}$ receptor and retinoid $\mathrm{X}$ receptor-alpha expression in human hepatocytes: synergistic increase of CYP3A4 induction by pregnane $\mathrm{X}$ receptor activators. Molecular Pharmacology 58 361-372.

Pascussi JM, Gerbal-Chaloin S, Fabre JM, Maurel P \& Vilarem MJ $2000 b$ Dexamethasone enhances constitutive androstane receptor expression in human hepatocytes: consequences on cytochrome P450 gene regulation. Molecular Pharmacology 58 1441-1450.

Patterson RLS 1968 5 $\alpha$-Androst-16-ene-3-one: compound responsible for taint in boar fat. Fournal of Science and Food Agriculture $1931-38$.

Quintanilla R, Demeure O, Bidanel JP, Milan D, Iannuccelli N, Amigues Y, Gruand J, Renard C, Chevalet C \& Bonneau M 2003 Detection of quantitative trait loci for fat androstenone levels in pigs. Fournal of Animal Science 81 385-394.

Raeside JI \& Renaud RL 1983 Estrogen and androgen production by purified Leydig cells of mature boars. Biology of Reproduction $28727-733$.
Raeside JI \& Christie HL 1997 Estrogen concentrations in semen of the stallion. Animal Reproduction Science 48 293-300.

Raeside JI, Renaud RL \& Friendship RM 1989 Aromatization of 19-norandrogens by porcine Leydig cells. Fournal of Steroid Biochemistry 32 729-735.

Saini SP, Sonoda J, Xu L, Toma D, Uppal H, Mu Y, Ren S, Moore DD, Evans RM \& Xie W 2004 A novel constitutive androstane receptor-mediated and CYP3A-independent pathway of bile acid detoxification. Molecular Pharmacology 65 292-300.

Saner KJ, Suzuki T, Sasano H, Pizzey J, Ho C, Strauss JF, Carr BR \& Rainey WE 2005 Steroid sulfotransferase 2Al gene transcription is regulated by steroidogenic factor 1 and GATA-6 in the human adrenal. Molecular Endocrinology 19 184-197.

Schwarzenberger F, Toole GS, Christie HL \& Raeside JI 1993 Plasma levels of several androgens and estrogens from birth to puberty in male domestic pigs. Acta Endocrinologica 128 173-177.

Shibutani S, Shaw PM, Suzuki N, Dasaradhi L, Duffel MW \& Terashima I 1998 Sulfation of alpha-hydroxytamoxifen catalyzed by human hydroxysteroid sulfotransferase results in tamoxifen-DNA adducts. Carcinogenesis 19 2007-2011.

Sinclair PA \& Squires EJ 2005 Testicular sulfoconjugation of the 16-androstene steroids by hydroxysteroid sulfotransferase: its effect on the concentrations of 5 alpha-androstenone in plasma and fat of the mature domestic boar. Fournal of Animal Science 83 358-365.

Sinclair PA, Hancock S, Gilmore WJ \& Squires EL 2005 Metabolism of the 16-androstene steroids in primary cultured porcine hepatocytes. Fournal of Steroid Biochemistry 96 79-87.

Song CS, Echchgadda I, Baek BS, Ahn SC, Oh T, Roy AK \& Chatterjee B 2001 Dehydroepiandrosterone sulfotransferase gene induction by bile acid activated farnesoid X receptor. Fournal of Biological Chemistry 276 42549-42556.

Squires EJ \& Lundström K 1997 Relationship between cytochrome P450 IIE1 in liver and levels of skatole and its metabolites in intact male pigs. Foumal of Animal Science 75 2506-2511.

Stahl F, Schnorr D, Pilz C \& Dorner G 1992 Dehydroepiandrosterone (DHEA) levels in patients with prostatic cancer, heart diseases and under surgery stress. Experimental Clinical Endocrinology 99 68-70.

Strott CA 1996 Steroid sulfotransferases. Endocrine Reviews 17 670-697.

Strott CA 2002 Sulfonation and molecular action. Endocrine Reviews 23 703-732.

Tan HS \& Raeside JI 1980 Developmental patterns of plasma dehydroepiandrosterone sulfate and testosterone in male pigs. Animal Reproductive Science 3 73-81.

Tanaka M, Matsumoto T, Yanai S, Domukai M, Toki D, Hayashi T, Kiuchi S, Yasue H, Uenishi H, Kobayashi E \& Awata T 2003 Conservation of the syntenies between porcine chromosome 7 and human chromosomes 6,14 and 15 demonstrated by radiation hybrid mapping and linkage analysis. Animal Genetics 34 255-263.

Thomae BA, Eckloff BW, Freimuth RR, Wieben ED \& Weinshilboum RM 2002a Human sulfotransferase SULT2A1 pharmacogenetics: genotype-to-phenotype studies. Pharmacogenomics Fournal 2 48-56.

Tsai MJ \& O’Malley BW 1994 Molecular mechanisms of action of steroid/thyroid receptor superfamily members. Annual Reviews in Biochemistry 63 451-486.

Weinshilboum R \& Aksoy I 1994 Sulfation pharmacogenetics in humans. Chemistry, Biology Interactions 92 233-246.

Received 18 August 2005 Accepted 20 December 2005 